\title{
Resistances to Gender Mainstreaming: An Analysis of the Trend of Women Engagement in Participatory Gender-Responsive Budgeting in Bangladesh
}

\author{
Shuvra Chowdhury* \\ Department of Public Administration, Faculty of Social Sciences, University of Rajshahi, \\ Rajshahi, 6205, The People's Republic of Bangladesh.
}

Received: 2020-06-26; Accepted: 2020-10-02; Published: 2020-10-27

\begin{abstract}
Gender Responsive budgeting (GRB) is among a few approaches for gender mainstreaming that has been introduced by the governments around the world or international funding organizations to institutionalize gender equality in public reforms. The formal processes of planning and budgeting at the Union Parishad (UP) - the lowest administrative tier of Bangladesh-offer general citizens to raise their demands at the local level. Besides, there is a provision that a 30\% fund will be earmarked for women. In this paper, the case of UP gender budgeting practice was analyzed from a gender perspective. On the basis of case oriented qualitative research strategy, this was an empirical study of 06 (six) UPs of three different districts of Bangladesh. The data of this study indicated that members of the NonGovernment Organizations (NGO) played a catalyst role in enhancing the access of women in the UP planning and budgeting processes. Along with the existing problems of local-level planning, lack of fiscal decentralization including resource constraint, absence of women development funding, the absence of women administrative officers at the different layers of government offices and obstacles and resistances in religion and patriarchal dimensions are inhibiting women to participate in the participatory processes. For implementing the GRB reform agenda suggestions are made for creating independent women budget groups at the local government level and researching on a broader perspective on GRB issues at the central government level.
\end{abstract}

Keywords: Resistances; Gender Responsive Budgeting; Gender mainstreaming

How to Cite: Chowdhury, S. (2020). Resistances to Gender Mainstreaming: An Analysis of the Trend of Women Engagement in Participatory Gender-Responsive Budgeting in Bangladesh. Journal of Contemporary Governance and Public Policy, 1(2), 53-66.

Permalink/D0I: https://doi.org/10.46507/jcgpp.v1i2.24 


\section{Introduction}

In common parlance, 'Gender Responsive Budgeting' (hereinafter GRB) brings together two issues that are not commonly associated with one another: gender equality and public financial management. Before going to the analysis of the concept of gender equality it should be preconceived by the readers that biological differences between males and females i.e. sex are different from the concept of gender. Gender equality means a society free from any discrimination of the social roles between men and women or girls and boys that are constructed by society. It means men/women's equal access in family, social, and state institutions. It is about the absence of domination of one class over another based on biological identities. However, it is claimed that gender equality could be one of the "less achieved promises of modernity" and there is a lack of adequate understanding of criteria and mechanisms, initiatives that can be institutionalized for gender equality and the needs of public administration as well (Lee-Gosselin, Briere, \& Ann, 2013).

Gender mainstreaming is a good governance tool to promote gender equality (Panday, forthcoming; Woodward, 2008). Participatory democracy and bureaucratic or technocratic mechanisms are regarded as two important approaches of implementation of the gender mainstreaming program (Mukhopadhyay, Steehouwer, \& Wong, 2006). In a broader perspective, the GRB approach both accumulate participatory democracy and bureaucratic mechanism. Uniting the two concepts democracy and bureaucracy are all about the governance of public organizations. According to the words of Hughes (2003, p. 76) "governance is a broader concept describing forms of governing which are not necessarily in the hands of the formal government". Government and governance are two distinct issues. Government is the institution itself while governance means networking among individuals, actors, and institutions of various types including private, public, philanthropic, etc. However, in the international framework for gender equality, the issue of a gender perspective is integrated into the budgetary decisions on policies and programs with adequate financing for programs and devised a system to track the allocations for gender equality and women empowerment (Beijing Platform for Action \&indicator 5.c.1 of agenda 2030 for Sustainable Development Goal).

If budgeting is considered as a "decision making process" then it is inevitable that gender equality is supposed to consider as its one of the important focus. In this perspective GRB refers to analysis of the entire budget through a gender lens to identify gender-differential impacts and to translate gender commitments into budgetary commitments (United Nation Development Programme, 2010, p. 3). Relevant literatures logically differentiate the roles, responsibilities and capabilities of both men and women and put demand of five important things to establish GRB approach: First, acknowledging the economic significance of the reproductive (household) sector and the need for public investment in these activities; secondly, the roles, responsibilities and capacities of men and women must not be stereotyped with a preconceived perception. It is to be perceived that both men and women play different roles, they have different responsibilities and capabilities. Thirdly, recognition of gender- neutral allocation of budgetary resources; 
fourthly, examining the welfare outcomes of the budget on men and women and boys and girls; and; finally, creating an enabling condition for women to participate in the economic growth process" (Government of Bangladesh, 2012, p. 5). This approach assures that it is necessary to pay off the contribution of unpaid household activities of women and recognition of the reproductive role of the women. Also, there are some imperatives for changes: the women should not be confined only in household activities and they should be engaged proactively in other activities other than household activities. In other words they must have choice. However, measuring welfare outcomes and creating enabling conditions are not easy task. There are four critical elements concerning GRB which are necessary for addressing the above mentioned approach to identify significance of women's unpaid work and different roles they play. First, mandatory earmarking of a certain percentage of budgetary allocation; secondly, an alternative to the "top down approach of gender budgeting". Because top down recipe is similar as "one size fits all" cannot ensure gender equality; thirdly, scope for increasing number of women in administration. It is assumed that large number of women can alter the preference in favor of women; and Fourthly, budgeting through fiscal decentralization offers an opportunity to mapping local level gender needs (United Nation Development Programme, 2010, p. 4).

One may ask: why and how women are related to the public financial management processes? The answer can be made from an economic perspective since the World Bank (World Bank, 2007, p. 42) states that gender inequality is a barrier to growth and poverty reduction. Data shows that women are in inferior condition compared to their male counterparts in every indication including administrative, political, and economic. The underlying fact behind this approach is that women are more likely than men to have responsibility for unpaid work which reduces their time available for paid work and other things. Thus, women get less scope for paid work and lower levels of income and wealth as well. As a result, family responsibility: caring and nurturing other family members is perceived as women role while bread earning is perceived as the role of men (Alkadry \& Tower, 2014; D'Agostino, 2017). As a result, women continue to be underrepresented in public life, and violence and abuse of women and girls continue to be widespread and underreported. The broader objective to make a relationship between women and financial management is to create a society of freedom, equality, and justice for women. GRB initiatives seek to improve the outcomes of budgets in general, and gender equality and women's empowerment in particular. Budgeting and allocating resources to the women through their direct engagement in the planning and budgeting process can be a solution for long-existing inequality in almost every society. This is for the engagement of more women in public financial management and as the beneficiary as well. GRB as a tool of gender mainstreaming was first introduced in Australia in 1984 (Rubin \& Bartle, 2005). Consequently, several other countries along with India, Nepal, and Sri Lanka in South Asia introduced GRB respectively in 1998 and 2001. The Commonwealth report (2009) on Bangladesh indicated that application of the issue GRB was initiated in Bangladesh in the year 2001 which was supported by the Royal Netherlands Embassy and the Royal Norwegian 
Embassy (Government of Bangladesh, 2012).

\section{Participatory Gender Responsive Budgeting Process in Bangladesh:}

In the Indian sub-continent lack of right including property, vote, access in any sort of political process, education, right to remarriage of the widow women etc. and other social norms including dowry during child marriage, child marriage, poligamy and shahamoron (burning of a widow on the funeral pyre of her dead husband) were common features of women's life. The nineteenth and twentieth centuries are regarded as a landmark for advancement of the women all over the world (Khan, 2000, p. 86). Considering GRB as crosscutting issue there have been many reform initiatives in both the central and local government budgeting in Bangladesh during the past twenty years. The government has introduced the medium term budget framework to replace the traditional budget preparation system. The traditional planning process in Bangladesh followed a "top down approach" for planning as these are made by professional planners and the regional and local plans are made under the direction of central planners (Chowdhury, 2017; Zahid \& Rahman, 1994) while the medium term budget framework "integrates policy, planning, and budgeting within a medium-term framework" (estimates for 1 year, and projection for 4 years) (Government of Bangladesh, 2012, p. 9). There are policies for inclusion of women in the planning process including the National Women Development Policy-2011, the Seventh Five Year Plan (SFYP-20162020) and the National Rural Development Policy. The Ministry of Finance has started preparing documents that explain how different activities of all the ministries/divisions have implications for women's advancement and rights and analyzing gender-disaggregated data against various projects since the FY 2009-2010 (Begum, 2014).

The laws operate respective local institution outline the process through which the people at the urban and rural level are supposed to engage with the local level policy, planning and budget formulation process. This study is confined with the participatory gender responsive budgeting process of Union Parishad (UP). The formal processes of planning and budgeting at the Union Parishad (UP) - the lowest administrative tier of Bangladesh- offer general citizens to raise their demands at the local level. The other two tiers are Upazila (UZP), at the sub-district level, and Zilla Parishad (ZP) at the district level. These units have elected officials. The present Awami League Government came in power in 2008 and enacted laws which provided for comprehensive participation of people in the planning process. Among these the local government (Union Parishad) Act, 2009 (hereinafter the UP Act, 2009) offers people the opportunity of direct engagement to identify problems, related to their livelihoods, at the Ward level. According to section 9 and 10 of the UP Act, 2009, each UP is divided into nine wards. Each UP consists of one elected chair and twelve elected members, of whom nine are elected from the nine Wards and three women members are elected from three reserved seats (one for every three wards) exclusively for women. The respective female ward member of three wards acts as advisor of the meeting of WS and is responsible for ensure participation of female voters of three wards while the respective ward member is responsible for attaining the female voters of only one ward. The section 4 and 5 of the UP Act of 2009 
state that a Ward Shava (meeting at ward hereinafter WS) must be held in each Ward and shall include all the voters enlisted in the voter lists. The respective female ward member of three wards acts as advisor of the meeting of WS. So, the female ward member is responsible for ensuring participation of female voters of three wards while the respective Ward Member (WM) is responsible for attaining the female voters of only one ward. According to Section 57 of the UP Act, 2009 the prioritized plans of WS are supposed to disseminate in an open place in front of all the voters. This is called Open Budget Meeting (OBM). The women elected officials and voters, actors from civil society, feminist policy makers, members of women group are supposed to come together to these participatory spaces and express their demands and act as pressure group to ensure gender equality. The decision making process at WS i.e. formulation of prioritized demands of people is regarded here as participatory planning and approval of prioritized demands for implementation at the OBM is regarded here as participatory budgeting process. The members of the ward committee including respective female ward member, ward member, member of civil society organization, social worker, freedom fighter, school teachers are responsible for organizing WS. They are supposed to mapping social needs, resource classification and need identification before discussion of the needs of the general people at the WS. Engagement of members including expert on local matters, government officials, elected official, social workers in thirteen standing committees are made obligatory to scrutinize and finalize the plans of WS. The local governments units receive sector-wise allocation from the budget under the Annual Development Plan (ADP), donor driven project allocations and in the name of social safety net programs etc. These funds are allocated and disbursed to UP under the supervision of the transferred department of central government at the sub district level government offices. There is a provision of earmarking $30 \%$ project allocation of donor driven project for women. Gender responsive participatory budgeting is thus budgeting with those allocation keeping in mind the different needs of both men/women and boys/girls of the society. In this perspective, this paper intended to answer the question: Does participatory gender-responsive budgeting matter for women engagement in governance? On the basis of empirical data this paper explains the outcomes and the limitations of the GRB in the local government planning and budgeting processes.

\section{Research Methods}

Based on both primary and secondary data this study was carried out in six local government units of three different districts of Bangladesh. The primary data was collected from various financial statements of the financial year 2012-13 which included: budget statements, real income expenditure statements, preliminary demand lists that were taken at the ward level budget, final budget list, various beneficiary lists of government projects etc. Participatory processes in the planning and budgeting were observed and interviews were conducted with general citizen and government officials to understand the process of participatory democracy and bureaucratic or technocratic mechanisms. One type has been used for local government officials (Chairman, Members, and Secretary as administrative unit) and another type was used for local people who have 
participated planning and budgeting process. In addition to the above, one more type of questionnaire was used for Key Informants (KI) including elected official of sub district level, social welfare officer, chief executive officer of sub district, sub district level women affair officer and non-government officers etc. A total of 162 people were interviewed.

The study also carried out a Focus Group Discussion (FGD) at Union Parishad level for those who did not participate at planning and budgeting process. In each ward, two FGD sessions (one for male and another for female) were conducted for better understanding the issues why general people did not participate in that process. Homogeneity of participants was maintained in FGD sessions and each FGD session included 8-12 poor local inhabitants, depending upon their availability for this purpose. A total 323 people participated at those FGDs. A direct observation has been made of the functioning of various WSs in the Hariyan and the Kakina UP and OBMs of the Gogram, the Hariyan, the Ghurka, and the Hatikumrul UPs. The researcher and team observed the entire meeting. The meeting time, place, information transmission medium have also been noted for a better understanding of the process of planning. How information regarding planning and budgeting was disseminated in the UP's premises and locality has also been taken into consideration. The style of demand raising capacity of the poor people, as well as the style of answerability and responsiveness of UP functionaries, were also observed. Secondary data were collected from published documents (books, journals, magazines, newspapers, etc.), unpublished theses, and reports of various commissions and committees, research monographs, and browsing the internet.

\section{Result and Discussion}

GRB is among a few approaches for gender mainstreaming that has been introduced by the government or international funding organizations to institutionalize gender equality in public reforms. The participatory process allows people to participate in government institution while bureaucratic mechanism relies more on experts in gender mainstreaming to identify priorities or programs. There are many reform initiatives at the central government level in Bangladesh, especially at the ministry level including introducing medium term budget framework, instruction of mandatory displaying gender disaggregated data in the financial statement of all the ministries and disclosure of those information through respective ministry's website etc. (Begum, 2014; Chowdhury \& Panday, 2018; Government of Bangladesh, 2012). In the perspective of many reforms in the central government this study is intended to explore whether the participation of women in the participatory budget-making process at the local level can contribute to the governance process or not. This has been analyzed from two perspectives:

First, to evaluate the role of the elected women leader and women in administration in the process of making plans and budget. This was evident that the female ward members performed their duty of assisting the participation of the female voters in their localities. The Act prescribed mandatory participation of at least 5 percent voters of total voters of a Ward. The prescribed participation requirement was only achieved in the Hariyan and Kakina UPs and women participated in the WS meeting in larger numbers. They participated in the meeting to prioritize the demands of their daily life and discuss problems. The data of this study 
found that women had access to those meetings. They were invited and allowed to speak up at the meeting place. They placed their demand in the meeting. In the other UPs, the role of the women ward members was passive and they didn't play their role. The participatory processes of planning and budgeting are the requirement of donor's conditionality for getting funds. The UPs have been receiving donor's fund in the name of the Local Governance Support Project (LGSP) and currently it is in its third phase (20172022), with financial assistance from the World Bank. For getting this project fund participation of voters is a key precondition. The elected members, while interviewed, were found not aware of the gender dimensions of budgeting. The data of this study found variation in the participation of both men and women in a total 18 Wards while there are fake entries of name of the participants and the meetings were paper work only. However, no elected women or government officials were found in the meeting time. It seems participation as means for getting donor's fund. The possible reasons for it can be relate with the broader perspective of governance discussed in the introductory section. It is evident that there is an absence of engagement of organized groups of academia, feminist policymakers, and civil society organizations for implementing the policy of gender-responsive budgeting. There is no organized women budget group in Bangladesh to act as a pressure group to identify the agendas for the implementation of gender needs. However, Practical example shows it is necessary to networking among women to raise women's voice. For example: the Women Budget Group (WBG) of United Kingdom (UK) produced a resourceful case book for GRB. For them GRB is a tool to bring about change. In the other word it means a process of persuasion among the policy makers (government, parliament, civil servants). In this process impact of spending and revenue raising decisions are supposed to be evaluated to bring about changes in greater gender equality. The group thus suggested for organized women budget group and potential membership of academia, feminist policy makers and civil society organizations.

Now a pertinent question is: who is making decisions about policies, programs and projects at the local level In Bangladesh? The data of the Ministry of Finance summarized (Table-1) the male and female employment structure of the local government division across its different departments and agencies. Despite there were projects explicitly pro-women; their involvement in providing the service delivery process is very low. The data table showed that in 2011 only 3.4 percent of total numbers of officials employed in this sector were women and an overwhelming 96.6 percent were male. There were 11.4 percent , 3.3 percent , 11.6 percent, 15.9 percent, 4.4 percent, 1.5 percent 12 percent, 7.5 percent and 2.5 percent women were officer in the year 2010-11 while 14.9 percent, 9 percent, 17.9 percent, 15.9 percent ,4.4 percent, 1.5 percent, 12 percent, 7.5 percent, 2.5 percent women's were officer in the year 2009-10 in the Secretariat, Rural Development Institutions, Autonomous bodies and others, Local Government Engineering Department (LGED), district offices, Upazila Offices, Department of Public Health Engineering, District Offices and Upazila Offices. In the other data set it is evident that 13 percent , 0 percent , 7.7 percent, 22.1 percent, 1.2 percent, 3.8 percent, 7.1 percent, 8.6 percent and 1.6 percent women were office staff in the year 2010-11 while 11.3 percent, 0 
percent, 21.9 percent, 22.1 percent ,1.2 percent, 3.8 percent, 7.1 percent, 8.6 percent, 1.5 percent women's were office staff in the year 2009-10 in the Secretariat, Rural Development Institutions, Autonomous bodies and others, Local Government Engineering Department (LGED), district offices, Upazila Offices, Department of Public Health Engineering, district Offices and Upazila Offices .

Tabel 1. Male and Female Employment Structure by Agencies

\begin{tabular}{|c|c|c|c|c|c|c|c|c|}
\hline \multirow[t]{3}{*}{ Administration/ Agencies } & \multicolumn{2}{|c|}{ 2010-11 } & \multicolumn{2}{|c|}{ 2009-10 } & \multicolumn{2}{|c|}{$2010-11$} & \multicolumn{2}{|c|}{ 2009-10 } \\
\hline & \multicolumn{4}{|c|}{ Officers } & \multicolumn{4}{|c|}{ Staffs } \\
\hline & $\begin{array}{l}\text { Male } \\
(\%)\end{array}$ & $\begin{array}{c}\text { Female } \\
(\%)\end{array}$ & $\begin{array}{l}\text { Male } \\
(\%)\end{array}$ & $\begin{array}{c}\text { Female } \\
(\%)\end{array}$ & $\begin{array}{l}\text { Male } \\
(\%)\end{array}$ & $\begin{array}{c}\text { Female } \\
(\%)\end{array}$ & $\begin{array}{l}\text { Male } \\
(\%)\end{array}$ & $\begin{array}{c}\text { Female } \\
(\%)\end{array}$ \\
\hline Secretariat & 88.6 & 11.4 & 85.1 & 14.9 & 87 & 13 & 88.7 & 11.3 \\
\hline $\begin{array}{l}\text { Rural Development } \\
\text { Institutions }\end{array}$ & 96.7 & 3.3 & 91 & 9 & 100 & 0 & 100 & 0 \\
\hline $\begin{array}{l}\text { Autonomous bodies and } \\
\text { others }\end{array}$ & 88.4 & 11.6 & 82.1 & 17.9 & 92.3 & 7.7 & 78.1 & 21.9 \\
\hline $\begin{array}{l}\text { Local Government } \\
\text { Engineering Department }\end{array}$ & 84.1 & 15.9 & 84.1 & 15.9 & 77.9 & 22.1 & 77.9 & 22.1 \\
\hline District Offices & 95.6 & 4.4 & 95.6 & 4.4 & 98.8 & 1.2 & 98.8 & 1.2 \\
\hline Upazila Offices & 98.5 & 1.5 & 98.5 & 1.5 & 96.2 & 3.8 & 96.2 & 3.8 \\
\hline $\begin{array}{l}\text { Department of Public } \\
\text { Health Engineering }\end{array}$ & 88 & 12 & 88 & 12 & 92.9 & 7.1 & 92.9 & 7.1 \\
\hline District Offices & 92.5 & 7.5 & 92.5 & 7.5 & 91.4 & 8.6 & 91.4 & 8.6 \\
\hline Upazila Offices & 97.5 & 2.5 & 97.5 & 2.5 & 98.4 & 1.6 & 98.5 & 1.5 \\
\hline Total & 96.6 & 3.4 & 96.4 & 3.6 & 96.5 & 3.5 & 96.6 & 3.4 \\
\hline
\end{tabular}

Source: Ministry of Public Administration, adapted from Ministry of Finance (Government of Bangladesh, 2012:60-61)

As such, with these few government administrative officers, there are some elected political posts for women at a different level of local administration. At the UP level, there were three female ward members and at the UPZ level, there is one UPZ vicechair who is responsible for look after women related matters for a certain locality. There are women development forum (WDF) at the UPZ level but data revealed that it did not take projects from UP level. Theoretically, it was preconceived that women related issues would get preference if women's presence was visible at every sphere of politics and administration. In these circumstances one may encounter the following two reasons for not including women's demand in the development activities:
1. There is a lack of mechanism through which women's demands can be articulated from bottom to top level;

2. There is a lack of independent women budget group under administrative and political leadership.

Secondly, to evaluate the engagement of women as beneficiary and their ability to act as a pressure group in the participatory genderresponsive budgeting process. The data of this study found that women were able to place their demands in the meeting if they were invited by their ward members. The resolutions, as well as demand list of the WS, reveals that majority $64.10 \%$ (25 out of 39 ) raised their voice for various public welfare 
services including street light, safe water, public health while (24 out of 39 ) $61.54 \%$ citizens raised their demands of development and infrastructural programs and $23.08 \%$ (9 out of 39 ) raised their demands for inclusion of their name in various social safety net programs. After analyzing the variations of demands a claim can be made that WS meetings allowed people to place those demands in the public institution which are basic requirements for human life. It is also found that most of the people of this country reside in rural areas where there was a high demand for safe water, electricity, and public health-related service provisions (Chowdhury, 2015). Besides, the participants of the female FGD sessions for those who did not participate at the meeting (Number of FGD=18 \& Respondent=176) revealed that there was a high demand for employment opportunities for women. Employment opportunity for women they mean working with honor in their home or outside the home. The analysis of real income expenditure data revealed that the voices that were raised in the WS as demands were not taken into consideration for implementation considering gender dimension while the women were not aware of their role in the entire budgeting process; thus they didn't act as a pressure group.

The information disclosure at the website of local government division found some examples that explain how taking different projects were affecting women's life. The story of a successful beneficiary working at the "Small Scale Water Resources Development Project" of Local Government of Engineering Department (LGED) is analyzed here (Government of Bangladesh, 2020). Rozina Akhtar changed the course of her life through the membership of the project. Her husband was a low paid employee of a non-government organization (NGO) and he suddenly lost his job. They had six members in their family. She started receiving training from the project included cow fattening, poultry, and cattle rearing, vegetable gardening integrated crop management, seed preservation, tailoring, gender, and development as well as awareness building on the environment and took up a selfemployment initiative. Later she also participated in vocational and skill training programs. The post-training knowledge, skill, and financial returns leaded her to take up the teaching profession in a school. She continued her self-employed initiatives including poultry rearing, beef fattening, and tailoring by procuring a sewing machine. She passed the Higher Secondary Certificate examination and is currently pursuing her graduate degree while she has established a school with her own earning and opened furniture and crockeries shop for her husband.

However, the concept "preference for women" does not work every time in this way. The data (table2) revealed that almost all the UPs got the lion share of the annual fund allocation in the name of Test Relief, Food for Work, and Employment Generation Program, etc. These funds are spent on the creation of employment of the poor and disbursed from the Upazilla office. The beneficiaries work and get daily basis money or foodstuff. First, the poor only get this type of work for a certain period. This is not enough to lead their life with dignity. Secondly, the selection process of the beneficiaries for the work of infrastructure, repairing, and development activities through social safety disbursement are alleged with the corrupt act of local elected officials including bribe, nepotism, etc. (Chowdhury \& Panday, 2018). Again, 
the issue of equality remains questionable while the number of poor people is larger than the allocations are disbursed.

The following section thus shed light on the important findings of this paper.

\section{Absence of fiscal decentralization: Analyzing the trend "one size fits all"}

Generally, the budget provides a financial framework for decision making and resource allocation processes. Public financial management includes the government's income and expenditure and its management. Thus, GRB put a lens onto the government budgetary allocation that is supposed to ensure gender equality (Elson, 2001; Sharp \& Elson, 2012; Siddique, 2013).

Tabel 2. Analysis of local government funding: does one size fit all? (Amount in Taka, 1 Taka=0.012 Dollar)

\begin{tabular}{|c|c|c|c|c|c|c|c|c|}
\hline $\begin{array}{l}\text { UP wise } \\
\text { income }\end{array}$ & $\begin{array}{l}\text { House } \\
\text { Tax }\end{array}$ & $\begin{array}{c}\text { Income } \\
\text { Other } \\
\text { Than } \\
\text { House } \\
\text { Tax }\end{array}$ & $\begin{array}{c}\text { Salary } \\
\text { GoB Part }\end{array}$ & $\begin{array}{l}1 \% \text { fund } \\
\text { from } \\
\text { UPZ of } \\
\text { land } \\
\text { transfer }\end{array}$ & $\begin{array}{c}\text { Test Relief } \\
/ \\
\text { Food For } \\
\text { Work }\end{array}$ & $\begin{array}{c}\text { Annual } \\
\text { Developm } \\
\text { ent } \\
\text { Program }\end{array}$ & $\begin{array}{c}\text { Employment } \\
\text { Generation } \\
\text { Program }\end{array}$ & $\begin{array}{c}\text { Donors } \\
\text { NGO }\end{array}$ \\
\hline Hariyan & $2,59,402$ & $2,78,585$ & $1,68,675$ & $12,07,000$ & $39,32,425$ & $8,00,000$ & $3,25,000$ & $\begin{array}{c}13,72,19 \\
9\end{array}$ \\
\hline Gogram & 28,320 & 72,653 & $2,77,290$ & $2,29,600$ & $5,81,315$ & 0 & $29,19,000$ & $\begin{array}{c}18,06,03 \\
6 \\
\end{array}$ \\
\hline Ghurka & $1,91,560$ & $5,06,700$ & $6,23,458$ & $10,00,000$ & $41,48,028$ & $2,00,000$ & 0 & 0 \\
\hline Hatikumrul & $6,85,689$ & $2,16,453$ & $5,90,419$ & $9,00,000$ & $17,94,635$ & 0 & 0 & 0 \\
\hline Kakina & $5,46,000$ & $1,87,000$ & $6,43,700$ & $2,00,000$ & $22,25,000$ & $2,95,000$ & 0 & $\begin{array}{c}12,01,00 \\
0\end{array}$ \\
\hline Vadai & 63,440 & 12,700 & $3,41,378$ & 35,000 & 0 & $4,79,777$ & 0 & 0 \\
\hline
\end{tabular}

\begin{tabular}{|c|c|c|c|c|}
\hline $\begin{array}{c}\text { UP wise } \\
\text { expenditure }\end{array}$ & Establishment Cost & $\begin{array}{c}\text { Other } \\
\text { Expense }\end{array}$ & $\begin{array}{c}\text { Women } \\
\text { Development }\end{array}$ & $\begin{array}{c}\text { social safety net } \\
\text { program }\end{array}$ \\
\hline Hariyan & $6,65,751$ & 92,833 & $4,74,841$ & $70,52,060$ \\
\hline Gogram & $2,86,790$ & $1,03,437$ & $2,20,000$ & $52,61,073$ \\
\hline Ghurka & $6,23,458$ & $3,10,695$ & 0 & $50,75,308$ \\
\hline Hatikumrul & $5,67,423$ & 22,268 & 0 & $30,22,950$ \\
\hline Kakina & $11,84,800$ & $8,50,700$ & $2,00,000$ & $39,00,000$ \\
\hline Vadai & $3,57,828$ & 94,690 & 0 & $4,79,777$ \\
\hline Total & $36,86,050$ & $14,74,623$ & $8,94,841$ & $2,47,91,168$ \\
\hline
\end{tabular}

Source: Document review of real income expenditure statement of financial year 2011-12 (Document Review, 2014)

More specifically, it is a technique to analyze budgetary policies to evaluate its impact on gender equality. The proponents of this concept postulate that GRB is not about producing a separate budget for women. Instead, it aims to analyze any form of public expenditure, or method of raising public money, from a gender perspective, identifying the implications and impacts for women and girls as compared to men and boys (Elson, 2001; Sharp \& Elson, 2012). Fiscal decentralization allows the dispersal to other levels of government of previously-concentrated powers to tax and generate revenues by the central government only (Yuliani, 2004). The local government units of Bangladesh have limited sources to raise and retain financial resources and dependent on the central government largely for funding. The data table- 2 shows that the Hariyan, the Gogram, the Ghurka, the Hatikumrul, the Kakina and the Vadai UP received Taka 70,52,060, Taka 
52,61,073, Taka 50,75,308, Taka $30,22,950$, Taka $39,00,000$ \& Taka $4,79,777$ respectively under social safety net program. Women related programs including various social safety net programs without addressing gender inequality are considered as women's development. Most of the programs looked like a "welfare approach" while the government around the world is performing to achieve the targets of sustainable development goals following the gender and development (GAD) approach. The welfare approach concentrate on providing direct support in the form financial allocations to the females while emancipating women from all forms of discrimination and ensuring equality to their male counterpart are two important aspects of gender and development approach. The women having lack of human resources with technical knowledge is identified as key obstacle of this approach. This is particularly important in implementing strategies and plans relating to sector wise gender issues. This finding substantiates with the finding of Sharp \& Elson (2012). They also argued that women's needs and demands are often overlooked in in conventional budget and policy analysis and decision making process. The budget copies and the real income-expenditures of the UPs did not show that there were allocations for women-specific projects. However, explanations about how the other projects of other allocations could be helpful for women were also absent. Besides, women did not have access to the information on UPs resources. The group cohesion among women for selecting projects for themselves was also absent in the planning and budgeting practice at the local level. The women-only knew to go with a motion. The planning and budgeting practice through identifying their priorities of life did not confirm that those were enough for their real inclusion with the development activities or gender mainstreaming.

The involvement of nongovernment organizations (NGOs) and personal positive motive of elected officials are two important factors that are necessary for organizing participatory planning and budgeting process. In the Hariyan and Gogram UPs funding from NGOs was disbursed for hygiene and sanitation programs, for the establishment of tube well, distribution of some sewing machine for women, distribution of fishing net for group utilization. In the Kakina UP limited amount of funding from NGOs was disbursed for women's employment programs including spice cultivation, sewing machine and saving scheme. Now a pertinent question is: Did the demands those were raised at the ward level get funding? The data of this study also (table-2) found that only the Gogram, the Hariyan, and the Kakina UPs showed the expenditure head for women development while the other three UPs did not mention such accounts head in expenditure statement. The expenditure statement stated that the Gogram, the Hariyan, and the Kakina UPs received Taka 2,20,000, Taka $4,74,841$ and Taka 2,00,000 only respectively. The reason behind such an outcome is that the NGO officers motivated and trained the UP officers of Hariyan and Gogram UPs for prioritizing projects for women while the UP chair of Kakina earmarked funds for women.

\section{Obstacles and resistances in religion and patriarchal dimensions}

In some UPs, although they were informed, 4.55 per cent $(\mathrm{R}=176)$ of females did not attend at WS due to inconvenient meeting time and their hesitation to speak at public meetings, while $6.82 \%$ of females did not attend 
due to their purdah system and societal norms. Arguments arise from the perspective of purdha system (hiding of women) which is regarded as code and ethics of religion that creates impediments of women's political participation. This restriction is outcome of the existing cultures that are akin to Hinduism and absorption of Islamic belief in this sub-continent (Chowdhury \& Panday, 2018). The societal structure of Bangladesh has a pre-existing structure of customary relations. For example, data revealed that in many regions women didn't go outside home. Women, in general, did not provide their opinion on family matters which is fundamentally not democratic. From FGD data, it is evident that, although women had information regarding WS, they did not participate. One female respondent replied to the question "Why did you not attend the WS?" "My husband is very serious. He did not allow me to cast vote in an election. But if my husband allows me, I will attend the meeting next time"(FGD data, 2014). Most of the female participants at FGD reported that they were afraid to attend any government office. One participant in an FGD session started her experience in the following way: "If I visit the UP, the UP functionaries will make me explain whether my husband had allowed me to go there. The UP functionaries will complain to my husband. Once I went to the UP to get a VGF card. The UP functionary scolded my husband and asked him how he allowed me to go to the UP. My husband beat me when I returned home. From then on, I do not go there. We are poor and only watch other people getting various services from the UP." This example exposed how the male dominated societal structure inhibited women's access in state institutions. On the other hand elected women ward members were facing restrictions from two sets of people in the society: firstly, the family members do not allow them to work for the people, and secondly, the male counterparts do not accept them wholeheartedly and do not allow the FWMs to work with them. This seems that women should remain in the homestead only and perform household activities. It is observed that female ward members remained passive in the participatory processes while they were supposed to participate spontaneously in those processes. It has been revealed that women ward members play passive roles in terms of providing information regarding the participatory planning and budgeting process. Three women ward members have expressed this opinion while answering the question: "Why do you not provide information to the voters? "We, the female UP representatives, are always kept unaware of UP-related allocations. We did not look at any letters which come to the UP. It seems the male members know everything but we do not know anything. I do not know about the resources that are allocated to my Ward. How will I inform my voters?" (Interview data, 2014). Male dominated patriarchal societal setting restrict and limit women's freedom to participate in the participatory processes. Panday thus properly termed this situation as 'Barbie doll syndrome'. To him, "Barbie is there, you can see her, she is beautiful, yet no one listens to her and she can do anything unless someone moves her hands and feet for her" (Panday, forthcoming). This patriarchal attitudes restrict both the women to participate in the politics as elected women elected officials and beneficiaries. We must understand that the democratic model of participatory planning and budgeting has been devised without taking consideration of these issues. This can be claimed that gender-responsive participatory budgeting will not fit well 
in the rural social setting of Bangladesh without considering these perspectives.

\section{Conclusion}

Participation is regarded as one of the major conditions for good governance. The key challenges are societal and organizational expectation from women is still a work life issue for them. Participation is still low in the level of its rung as it has been used as a means for getting donor's fund. The researcher claims for active and spontaneous participation to act as a way of achieving an end i.e. access to women's own planning and budgeting process spontaneously and to act as pressure group. Woodward's (2008) finding thus found feasible in this study: devising new reforms are not easy to install and it is documented that the gender mainstreaming within organizations in practice faces many important challenges, attains mostly symbolic results, and does not fundamentally modify established policies and practices. Implementation of the GRB policy needs many changes including policy of budgeting through fiscal decentralization; increasing number of women in administration; engagement of organized groups of academia, feminist policy makers and civil society organizations; and organization of organized women budget group to act as pressure group to identify the agendas for implementation of gender needs. We should fully appreciate the amazing level of change that has, nonetheless, occurred following the reform efforts of the participatory planning and budgeting processes. The reform initiative for participatory planning and budgeting is not confined with the paperwork of government officials only, rather, direct civic engagement is found feasible in those processes. Networking among actors including NGOs \& local government, individuals and institutions are found workable in Bangladesh and many other countries in Asia, Africa, and Europe. It is evident that participatory gender-responsive budgeting matters for the engagement of women in governance. This process demands the fact that without women's involvement both in the demand and supply side budgeting cannot bring the desired outcome. Directly observing the participatory spaces it was also learnt that women can place their demands at the participatory spaces while the other issues including measures for eradicating violence against women, tackling trafficking, mental and physical harassment of women etc. need special management for getting fund from government. For gender-responsive budgeting imposing the direct tax or generating revenues from different sources locally and the autonomy of spending that money is necessary. From the above findings, it is evident that many challenges need to be resolved for the working of gender-responsive participatory budgeting. These challenges can be categorized into twopart:

First, reform should be done at the central government level. Measures should be taken to develop a model that will able to consider demands and needs of heterogeneous populace. Different people have different needs. Thus, attempts including survey, FGD, votes on needs, implementation and presentation, etc. from the central government can be taken to identify the needs of citizens following the example of Penang, Malaysia (Kamarudin, 2016).

Secondly, the Bangladeshi example can be workable if funding from top to bottom becomes possible in every feasible project. In this case, the creation of independent women budget group should be formed at the local government level with a coalition of 
academia, feminist policymaker, and members of civil society organizations. The democratic decision-making process and people's access to administration are two important elements of public management of the twenty-first century and the prerequisite for governance process as well. Without acting as a pressure group the diversified needs of men and women will be not addressed at the local level. Finally, the issue of gender analysis should not be under emphasized in the process of developing any new model of gender responsive budgeting both at the central and local government. The data of the study did not confirm that officials of the local level follow any

\section{References}

Alkadry, M. G., \& Tower, L. E. (2014). Women and public service: Barriers, challenges, and opportunities. Armonk, NY: M.E. Sharpe.

Begum, F. S. (2014). Gender equality and women's empowerment: suggested strategies for the 7th five year plan, General Economic Division (GED). Dh: Planning Commission, the Government of Bangladesh.

Chowdhury, S. (2015). Impact of 'the Local Government (UP) Act, 2009' on the local governance in Bangladesh: A focus on people's participation and accountability. University of Rajshahi, Rajshahi.

Chowdhury, S. (2017). Democratisation of local government planning in Bangladesh. Commonwealth Journal of Local Governance. 115134.

Chowdhury, S. \& Panday, P. K. (2018). Strengthening local governance in Bangladesh: Reforms, participation and accountability (Vol. 8). Cham: Springer. gender specific model for its budgeting process. Only earmarking a fixed amount of money cannot bring outcome while the diversified need identification is the first task of gender responsive budgeting process. For this, various established models including social relation, capability approaches, gender framework models and various empowerment framework should be taken into consideration.

\section{Acknowledgements}

This paper is drawn from $\mathrm{PhD}$ research, which was funded by a fellowship from Prime Minister's Office Fund for Higher Education, Bangladesh.

D'Agostino, M. J. (2017). Changing the narrative: The difference women make in public administration. Administration \& Society, 49(1), 9-19.

Elson, D. (2001). Gender Responsive Budget Initiatives: Some Key Dimensions and Practical Examples. Retrieved from Columbia Law School website: http://www2.law.columbia.edu/ faculty_franke/Gender_Devel/Els en Gender Sensitive Budgeting.pdf

Government of Bangladesh. (2012). Gender Budgeting Report, Government of the People's Republic of Bangladesh, The Ministry of Finance, Finance Division. Retrieved from www.mof.gov.bd

Hughes, O. E. (2003). Public management and administration: An introduction. Hampshire: Palgrave Macmillan.

Kamarudin, S. (2016). Gender Responsive and Participatory Budgeting in Penang: The People-Oriented Model. In Gender Responsive and 
Participatory Budgeting (pp. 5579). Springer.

Khan, A. A. (2000). Pararthoparatar Arthanity. Dhaka: The University Press Limited.

Lee-Gosselin, H., Briere, S., \& Ann, H. (2013). Resistances to gender mainstreaming in organizations: Toward a new approach. Gender in Management: An International Journal.

Marks Rubin, M., \& Bartle, J. R. (2005). Integrating gender into government budgets: A new perspective. Public Administration Review, 65(3), 259-272.

Mukhopadhyay, M., Steehouwer, G., \& Wong, F. (2006). Politics of the possible: gender mainstreaming and organizational change: experiences from the field. Amsterdam: KIT-Royal Tropical Institute.

Panday, P. K. (forthcoming). Women's participation in politics at the local level in Bangladesh: a perspective from good governancein N. Ahmed (ed), Public Policy and Governance in Bangladesh: Forty Years of Experience, PP 164-178, Dhaka: The University Press Limited.

Sharp, R., \& Elson, D. (2012). Budgeting for Equity: Gender budget initiatives within a framework of performance oriented budgeting. New York: United Nations Development Fund for Women.
Siddique, K. (2013). A case study of gender responsive budgeting in Bangladesh. The Commonwealth, 11, 19.

United Nation Development Programme. (2010). GenderSensitive Fiscal Policies: Experience of ex-post and ex-ante Gender Budgets in Asia-Pacific, Asia-Pacific Human Development Report Background Papers Series 2010/06.

Woodward, A. E. (2008). Est-il trop tard pour une approche intégrée de l'égalité? Cahiers Du Genre, (1), 95-116.

World Bank. (2007). A guide to participatory Budgeting. In A. Shah (Ed.), Participatory Budgeting. Public Sector Governance and Accountability series. Washington, DC: World Bank.

Yuliani, E. L. (2004). Decentralization, deconcentration and devolution: What do they mean. Interlaken Workshop on Decentralization, 27-30. Center for International Forestry Research Interlaken, Switzerland.

Zahid, S. J. A., \& Rahman, M. M. (1994). Framework on management of local level planning in Bangladesh. In A. Salehuddin \& S. J. A. Anwar (Eds.), Strategies and issues of local level planning in Bangladesh. Kotbari, Comillah: BARD.

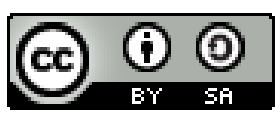

(C) 2020 by Author. Submitted for possible open access publication under the terms and conditions of the Creative Commons Attribution (CC-BY-SA) license (https://creativecommons.org/licenses/by-sa/3.0/). 